青年期および中年期禅宗修行僧における 血清脂質, 血糖值の生理学的相違

\author{
東口久づか ${ }^{1}$, 篠原能子 ${ }^{2}$, 松本仲子 ${ }^{3}$ ，菅原龍幸 4
}

(1秋田栄養短期大学，2駒沢女子短期大学，3桐生大学，4女子栄養大学)

\title{
Physiological difference of serum lipid and blood glucose levels between young and middle-aged Zen monks
}

\author{
Mizuka Higashiguchi ${ }^{1}$, Yoshiko Shinohara ${ }^{2}$, \\ Nakako Matsumoto ${ }^{3}$, Tatsuyuki Sugahara ${ }^{4}$ \\ ${ }^{1}$ Akita Nutrition Junior College, 46-1, Shimokitate, Sakura, Mamorisawa, Akita city, 010-8515 \\ ${ }^{2}$ Komazawa Woman's Junior College, 238, Sakahama, Inagi city, Tokyo, 206-8511 \\ ${ }^{3}$ Kiryu University, 606-7, Asami, Kasakake, Midori city, Gunma, 379-2392 \\ ${ }^{4}$ Kagawa Nutrition University, 4-46-14, Aoyama-bldg, Sengoku, Bunkyo-ku, Tokyo, 112-0011 \\ 1 \%010-8515 秋田市下北手桜字守沢 46-1 \\ 2 于206-8511 東京都稲城市坂浜 238 \\ 3 テ379-2392 群馬県みどり市笠懸町阿左美 606-7 \\ 4 テ112-0011 東京都文京区千石 4-46-14 青山ビル $2 \mathrm{~F}$
}

\begin{abstract}
The purpose of this study was to compare serum lipid and blood glucose levels in young and middle-aged Zen monks, and to clarify the influence on physiological change in body by aging. The eighteen Zen monks who lived in a Zen temple (a young group of twelve average aged 24.3, and a middle-aged group of six average aged 59.2) were investigated their body measurement, life activity survey, dietary survey, evaluation of health-related quality of life, and blood test.

As a result, a significant difference between the two groups was not recognized in BMI, body fat percentage, energy consumption, nutrient intakes, and evaluation of health-related quality of life. Identically, in both of the groups, a distinct difference was not observed in HDL cholesterol and triglyceride levels. However, total cholesterol and blood glucose levels of the young group were remarkably higher than those of the middle-aged group.

Therefore, this study suggested that physiological change in body by aging affected the total cholesterol and blood glucose levels.
\end{abstract}

\section{緒言}

心血管疾患の発症には, 高血圧, 而糖能異常, 脂質代 謝異常といった病態が密接に関連している。例えば，虚 血性心疾患の危険因子として血清脂質が重要な役割を持 つことが知られており11)2，高総コレステロール，高 LDL コレステロール, 高中性脂肪 3) 4), あるいは低 HDL コレステロール5) は, 虚血性心疾患のリスクを上 昇させることが報告されている。まだ糖尿病は虚血性心
疾患の臨床的危険因子の多くを上昇させることが知られ ており6）７，糖尿病患者はそうでない者より心血管疾患 の発症率が $2 \sim 4$ 倍以上高いことが報告されている8)。 このように, 血清脂質抢よび血糖の異常は心血管疾患 の主要な危険因子となるが，総コレステロール， LDL コレステロール, 中性脂肪, 血糖は年齢とともに増加す $3^{99-13)}$ 。その要因として, 運動量の減少 ${ }^{14)}$, 除脂肪体重 の減少15)，体脂肪量の増加16)が考元られるが，これらは 生活環境や生活習慣の改善により大部分の修正が可能で 
青年期および中年期禅宗修行僧における血清脂質, 血糖值の生理学的相違

ある。その一方, 臓器・組織の機能低下といった身体の 不可逆的な生理変化も, 脂質および糖代謝に何らかの影 響を及ぼすものと考えられる。しかし，これまで年齢と 血清脂質, 血糖との関連をみた報告は, 異なる生活環境 や生活習慣を有する者を対象に身体活動の低下や体組成 の変化との関連を検討したものが多く17１8），ヒトを対 象として加齢による身体の生理変化との関連を検討した 報告はほとんどみられない。

そこで本研究では, 禅宗僧堂で生活する修行僧を対象 に調査を行った。対象者は生活環境や生活習慣が相似し ていることから，社会・経済的要因および精神・身体的 要因の影響を除外した上での検討が可能であると思われ る。そして, 生活環境や生活習慣以外の要因, すなわち 加齢による身体の生理変化が血清脂質，血糖に及ぼす影 響を，青年期および中年期修行僧を比較することにより 検討を行った。

\section{研究方法}

\section{1. 対象者}

調査は平成17年 7 月に，禅宗僧堂で生活する男性の青 年期修行僧（以下，青年期）12名，中年期修行僧（以下, 中年期） 6 名，合計18名を対象に行った。対象者の平均 年齢は青年期 $24.3 \pm 2.3$ 歳, 中年期 $59.2 \pm 4.2$ 歳である。 また，平均修行期間は青年期 $10.5 \pm 7.3$ ヶ月，中年期 $11.8 \pm 11.7$ ヶ 調査時点まで契煙習慣，血圧降下剂，血糖降下剤の服薬 がなく，肥満ではない（Body Mass Index（BMI）25未 満）ことを確認した。

\section{2. 調査項目}

本研究の調査項目は, 身体計測, 生活活動調査, 食事 調査, 健康関連 QOL (Health-related Quality of Life) 評価, 血液検査とした。

身体計測には体脂肪計（TBF-102，TANITA 社）を 使用し，身長，体重から BMI を算出した。また，生体 インピーダンス法にて体脂肪率を測定した。

生活活動調査は連続した 3 日間行った。24時間の活動 動作をすべて記録するよう対象者に依頼した。活動動作 の記載に専門用語が多数見られたことから，その翻訳を 修行経験のある現役僧侶に依頼した。活動動作ごとに生 活活動強度を決定し，それに活動時間を乗じたものを合 計して 1 日のエネルギー消費量とした。

食事調査は，生活活動調査と同日の連続した 3 日間行 った。対象者が共通に摂取する朝食, 昼食, 夕食につい ては，料理名および調味料を含むすべての食品名の記録 と，盛付け後の食事の写真撮影を調理担当者に依頼した。 また，おかわり，間食，外食があった場合には料理名お よび食品名と，分量または概量の記録を対象者に依頼し た。摂取量は，これらの記録や食事写真に基づき資 料19)20)を参考に管理栄養士が推量した。エネルギー，炭 水化物, たんぱく質, 脂質, 飽和脂肪酸, 一価不飽和脂
肪酸，多価不飽和脂肪酸， $\omega 6$ 脂肪酸， $\omega 3$ 脂肪酸，コ レステロール, ナトリウム, カリウム, カルシウム, 食 物繊維の摂取量を，五訂日本食品成分表に準拠した栄養 計算ソフト（エクセル栄養君 ver.3.0）を使用して算出 した。

健康関連 QOL 評価には SF-36v2 日本語版 ${ }^{21)}$ を使用 し，自己記入式アンケートの記入を対象者に依頼した。 36項目の結果加ら, 身体機能, 日常役割機能 (身体), 身体の痛み, 全体的健康感, 活力, 社会生活機能, 日常 役割機能 (精神), 心の健康といった 8 項目の下位尺度 得点を求め, 日本人の標準值をもとに性 ·年齢を補正し た50点を平均とする偏差得点に換算して評価した。

血液検査項目は，総コレステロール，HDLコレステ ロール, 中性脂肪, 血糖とし, 早朝空腹時に肘前静脈か ら真空採血した血液検体を株式会社ビー・エム・エルに 委託し測定した。

\section{3 . 統計解析}

青年期および中年期の平均値の比較は，STATISTI$\mathrm{CA}^{\mathrm{TM}}$ Pro2000（Stat Soft ${ }^{\circledR}$ JAPAN）を使用して Student's t-testにより解析し, $p<0.05$ を統計学的有意 水準とした。

\section{4. 倫理的配慮}

すべての対象者にはヘルシンキ宣言の精神に則り，本 調査の目的, 内容, 方法, 情報の漏洩に注意することを 書面により説明し, 署名をもってインフォームドコンセ ントを得た。本研究は聖徳大学倫理委員会の承認を得た ものである。

\section{結果}

\section{1．身体特性}

対象者の身体特性を表 1 に示した。

BMI は青年期 22.4 に対し中年期 22.9 , 体脂肪率は青 年期17.5に対し中年期17.3 と，両群でほぼ同值であった。 エネルギー消費量は青年期 $2,927 \mathrm{kcal}$, 中年期 $2,662 \mathrm{kcal}$ と青年期で高かったが, 両群で有意差は認められなかっ た。

\section{2. 栄養素等摂取量}

対象者の栄養素等摂取量を表 2 に示した。 すべての栄養素等において，両群で有意差は認められ なかった。エネルギー摂取量は青年期 $2,612 \mathrm{kcal}$, 中年 期 $2,471 \mathrm{kcal}$ と，両群ともエネルギー消費量を下回った。 両群のたんぱく質, 脂質, 炭水化物のエネルギー比 （PFC 比）はおよそ12:22：67, 飽和脂肪酸, 一価不飽 和脂肪酸, 多価不飽和脂肪酸のエネルギー比（SMP 比） はおよそ $3 ： 4 ： 3 ， \omega 6$ 脂肪酸, $\omega 3$ 脂肪酸のエネル ギー比はおよそ5：1であった。コレステロール摂取量 は両群とも $100 \mathrm{mg} / 1,000 \mathrm{kcal}$ 程度であった。

\section{3 . 健康関連 $\mathrm{QOL}$ の評価}

対象者の健康関連 QOL 評価の結果を表 3 に示した。 身体機能, 日常役割機能 (身体), 全体的健康感, 社 
Table 1 Physical characteristics of the two-generation in Zen monks

\begin{tabular}{lccc}
\hline & $\begin{array}{c}\text { Young group } \\
(\mathrm{n}=12)\end{array}$ & $\begin{array}{c}\text { Middle-aged group } \\
(\mathrm{n}=6)\end{array}$ & $P$-value \\
\hline Height $(\mathrm{m})$ & $1.75 \pm 0.04$ & $1.69 \pm 0.03$ & $<0.01$ \\
Weight $(\mathrm{kg})$ & $69.1 \pm 8.5$ & $65.4 \pm 4.8$ & 0.34 \\
Body mass index $\left(\mathrm{kg} / \mathrm{m}^{2}\right)$ & $22.4 \pm 2.3$ & $22.9 \pm 1.6$ & 0.68 \\
Body fat mass $(\%)$ & $17.5 \pm 2.3$ & $17.3 \pm 3.8$ & 0.90 \\
Energy expenditure (kcal) & $2,927 \pm 298$ & $2,662 \pm 243$ & 0.08 \\
\hline
\end{tabular}

All values are means $\pm \mathrm{SD}$.

Table 2 Nutrient intakes of the two-generation in Zen monks

\begin{tabular}{|c|c|c|c|}
\hline & $\begin{array}{l}\text { Young group } \\
\qquad(\mathrm{n}=12)\end{array}$ & $\begin{array}{l}\text { Middle-aged group } \\
\qquad(\mathrm{n}=6)\end{array}$ & $P$-value \\
\hline Energy（kcal） & $2,612 \pm 630$ & $2,471 \pm 551$ & 0.42 \\
\hline Carbohydrate ( $\%$ of energy) & $66.7 \pm 5.9$ & $66.6 \pm 4.6$ & 0.94 \\
\hline Protein ( $\%$ of energy) & $11.8 \pm 2.4$ & $11.7 \pm 2.1$ & 0.82 \\
\hline Fat (\% of energy) & $21.5 \pm 4.7$ & $21.8 \pm 3.4$ & 0.75 \\
\hline SFA $(\%$ of energy $)$ & $4.7 \pm 2.3$ & $4.4 \pm 1.4$ & 0.62 \\
\hline MUFA（\% of energy） & $7.1 \pm 2.1$ & $7.3 \pm 1.8$ & 0.90 \\
\hline PUFA（\% of energy） & $6.2 \pm 2.0$ & $6.7 \pm 1.5$ & 0.33 \\
\hline Omega-6 PUFA ( $\%$ of energy) & $5.2 \pm 1.9$ & $5.6 \pm 1.6$ & 0.45 \\
\hline Omega-3 PUFA ( $\%$ of energy) & $1.0 \pm 0.6$ & $1.1 \pm 0.7$ & 0.46 \\
\hline Cholesterol (mg/1,000kcal) & $110.9 \pm 112.1$ & $102.1 \pm 108.7$ & 0.79 \\
\hline Sodium (mg/1,000kcal) & $2,600 \pm 850$ & $2,501 \pm 957$ & 0.70 \\
\hline Potassium (mg/1,000kcal) & $1,171 \pm 281$ & $1,269 \pm 257$ & 0.22 \\
\hline Calcium (mg/1,000kcal) & $243.6 \pm 98.6$ & $234.7 \pm 81.0$ & 0.74 \\
\hline Dietary fiber $(\mathrm{g} / 1,000 \mathrm{kcal})$ & $8.1 \pm 2.6$ & $9.1 \pm 1.6$ & 0.13 \\
\hline
\end{tabular}

All values are means \pm SD. SFA, saturated fatty acids; MUFA, mono-unsaturated fatty acids;

PUFA, poly-unsaturared fatty acids.

Table 3 Evaluation of health-related quality of life by difference at generation in Zen monks

\begin{tabular}{llcc}
\hline & $\begin{array}{c}\text { Young group } \\
(\mathrm{n}=12)\end{array}$ & $\begin{array}{c}\text { Middle-aged group } \\
(\mathrm{n}=6)\end{array}$ & $P$-value \\
\hline Physical functioning & $54.5 \pm 5.2$ & $50.4 \pm 5.3$ & 0.13 \\
Role physical & $51.2 \pm 9.1$ & $49.7 \pm 9.4$ & 0.72 \\
Bodily pain & $47.2 \pm 10.2$ & $46.6 \pm 10.4$ & 0.70 \\
General health perception & $53.1 \pm 8.2$ & $52.5 \pm 8.3$ & 0.19 \\
Vitality & $45.0 \pm 11.7$ & $44.3 \pm 11.9$ & 0.89 \\
Social functioning & $45.5 \pm 15.9$ & $44.5 \pm 16.2$ & 0.94 \\
Role emotional & $47.4 \pm 9.2$ & $47.7 \pm 9.5$ & 0.47 \\
Mental health & $43.2 \pm 11.5$ & $42.9 \pm 12.0$ & 0.82 \\
\hline
\end{tabular}

All values are means \pm SD.

Table 4 Blood test values of the two-generation in Zen monks

\begin{tabular}{lccc}
\hline & $\begin{array}{c}\text { Young group } \\
(\mathrm{n}=12)\end{array}$ & $\begin{array}{c}\text { Middle-aged group } \\
(\mathrm{n}=6)\end{array}$ & $P$-value \\
\hline Total cholestelol $(\mathrm{mg} / \mathrm{dL})$ & $174 \pm 35$ & $219 \pm 33$ & 0.02 \\
HDL cholestelol $(\mathrm{mg} / \mathrm{dL})$ & $54 \pm 10$ & $60 \pm 11$ & 0.28 \\
Triglyceride $(\mathrm{mg} / \mathrm{dL})$ & $78 \pm 47$ & $113 \pm 43$ & 0.14 \\
Blood glucose $(\mathrm{mg} / \mathrm{dL})$ & $87 \pm 5$ & $98 \pm 10$ & 0.01 \\
\hline
\end{tabular}

All values are means \pm SD. HDL, high-density lipoprotein. 
会生活機能, 日常役割機能（精神）の項目において青年 期で高い值を示した。しかし，すべての項目において両 群で有意差は認められなかった。

\section{4 . 血清脂質および血糖値}

対象者の血清脂質および血糖値を表 4 に示した。 HDL コレステロール, 中性脂肪では中年期で高い值 を示したものの両群で有意差は認められなかった。しか し, 総コレステロールでは青年期 $174 \mathrm{mg} / \mathrm{dL}$ に対し中年 期 $219 \mathrm{mg} / \mathrm{dL}$, 血糖では青年期 $87 \mathrm{mg} / \mathrm{dL}$ に対し中年期 $98 \mathrm{mg} / \mathrm{dL}$ と, 青年期よりも中年期で有意に高い值を示 した（総コレステロール $: p=0.02$, 血糖 $: p=0.01$ )。

\section{考察}

\section{1. 加齢による血清脂質および血糖の変化}

両群で有意差が認められなかった HDL コレステロー ルと中性脂肪に関する国民健康・栄養調査結果22)では, 男性に打いて HDL コレステロールは年齢階級による差 がほとんどみられなかったが，中性脂肪は $40 〜 49$ 歳まで 増加しそれ以降漸減した。米国の National Health and Nutrition Examination Survey（NHANES）吕において も同様の傾向が報告されている ${ }^{23)}$ 。したがって HDL コ レステロールは, 生活環境や生活習慣, あるいは加齢に よる身体の生理変化といった要因の何れも特異的に反映 するものではないことが考元られた。Lemieux ら ${ }^{177} は$ は, 男性に打いて中性脂肪は青年期よりも中年期で有意に高 いが，内臟脂肪面積で中性脂肪值を補正することにより 有意差が消失することを報告している。したがって中性 脂肋は, 生活環境や生活習慣の影響を受けやすく加齢に よる身体の生理変化の影響は反映されにくい可能性があ った。

両群で有意差が認められた総コレステロールと血糖に 関する国民健康・栄養調查結果では, 男性において総コ レステロール值は 50 ～59歳まで増加しそれ以降漸减した が，血糖值は年齢階級が上がるにつれ増加した。総コレ ステロール值においては NHANESIIIでも同様の傾向が 報告されている。前述の Lemieux らは, 男性に扔いて 総コレステロールは, 青年期よりも中年期で有意に高く 内臟脂肪面積で総コレステロール值を補正しても值に変 化が生じないことを報告している。したがって総コレス テロール值は, 生活環境や生活習慣の影響は受けにくい が加齢による身体の生理変化の影響は反映されやすい可 能性があった。Petersen ら ${ }^{24)}$ は, 身体活動量, 体脂肪 量, 除脂肪体重を一致させた青年期㧍よび高齢期男性の インスリン抵抗性を比較し, 高齢期で有意に高いことを 報告している。したがって血糖値は，加齢による身体の 生理変化の影響が反映される可能性があった。

\section{2. 禅宗修行僧の生活環境亡生理学的影響}

本研究の対象者は禅宗僧堂で生活していることから, 生活環境や生活習慣が相似している集団であると考えら れる。事実, 両群に扔いて BMI, 体脂肪率, エネルギー
消費量, 栄養素等振取量, 健康関連 QOL といった調査 項目に有意差は認められなかった。このことから, 血清 脂質打よび血糖に大きく影響を及ぼすと考えられる社 会・経済的要因抢よび精神・身体的要因といった交絡因 子は, 調査開始時点ですでに除外されていることがわか った。したがって本研究では, 生活環境や生活習慣以外 の要因である加齢による身体の生理变化が血清脂質およ び血糖に及ぼす影響を，直接的に検討することが可能で ある。

\section{3. 本研究の調查対象者と遺伝的要因}

本研究では, 禅宗僧堂で生活する修行僧は青年期の者 が圧倒的に多いことから，必然的に中年期の対象者数を 少なくせざるを得なかった。しかし, 両群はともに禅宗 僧堂で生活しており, 生活環境や生活習慣が相似してい ることから, 本研究における系統的な誤差は小さいもの と考えられる。また本研究では, 対象者に扔ける遺伝的 要因の違いが, 両群の血清脂質および血糖值にどの程度 影響したのか把握することができなかった。しかし，加 齢とともに遺伝子の発現量は变化し ${ }^{25)}$, 遺伝的要因より も生活環境や生活習慣の影響が大きく反映されるように なることから 26 , 青年期と中年期の血清脂質および血糖 值を比較した本研究において対象者に打ける遺伝的要因 の違いは, 結果にそれほど影響しないものと考えられる。

本研究は, 財団法人日本科学協会の平成 17 年度笹川科 学研究助成によって実施したものである。

\section{要 約}

青年期および中年期修行僧の血清脂質, 血糖值を比較 し，加齢による身体の生理変化の影響を検討することを 目的として, 禅宗僧堂で生活する男性修行僧18名（青年 期12名, 中年期 6 名）を対象に, 身体計測, 生活活動調 查, 食事調査, 健康関連 QOL 評価, 血液検査を行った。 その結果, BMI, 体脂肪率, エネルギー消費量, 栄養 素等摂取量, 健康関連 QOL において両群で有意差は認 められなかった。しかし, HDL コレステロール, 中性 脂肪では両群で有意差は認められなかったものの, 総コ レステロール, 血糖では青年期修行僧よりも中年期修行 僧で有意に高い值を示した（総コレステロール : $p=$ 0.02 , 血糖 $p=0.01)$ 。このことから, 総コレステロー ルおよび血糖值は, 加齢による身体の生理変化の影響を 受ける可能性が示唆された。

\section{文献}

1) Canadian consensus conference on cholesterol: final report. The Canadian consensus conference on the prevention of heart and vascular disease by altering serum cholesterol and lipoprotein risk Factors, Can. Med. Assoc. J., 139, 1-8 (1988)

2) NIH consensus conference : Lowering cholesterol to prevent heart disease, JAMA, 253, 2080-86 (1985) 
3) Castelli WP : Epidemiology of coronary heart disease : the Framingham study, Am. J. Med., 76, 4-12 (1984)

4) Fager G, Wiklund O, Olofsson SO, et al : Multivariate analyses of serum apolipoproteins and risk factors in relation to acute myocardial infarction, Arteriosclerosis, 1, 273-9 (1981)

5) Gordon DJ, Probstfield JL, Garrison RJ, et al : High-density lipoprotein cholesterol and cardiovascular disease. Four prospective American studies, Circulation, 79, 8-15 (1989)

6) Kannel WB, McGee DL : Diabetes and glucose tolerance as risk factors for cardiovascular disease : The Framingham study, Diabetes Care, 2, 120-6 (1979)

7) Stamler J, Vaccaro O, Neaton JD, et al : Diabetes, other risk factors, and 12-yr cardiovascular mortality for men screened in the multiple risk factor intervention trial, Diabetes Care, 16, 434-44 (1993)

8) Hurst RT, Lee RW : Increased incidence of coronary atherosclerosis in type 2 diabetes mellitus : mechanisms and management, Ann. Intern. Med., 139, 824-34 (2003)

9) Dedonder-Decoopman E, Fievet-Desreumaux C, Campos E, et al : Plasma levels of VLDL \pm LDL-cholesterol, HDLcholesterol, triglycerides and apoproteins B and A-I in a healthy population influence of several risk factors, Atherosclerosis, 37, 559-68 (1980)

10) Abbott RD, Garrison RJ, Wilson PW, et al : Joint distribution of lipoprotein cholesterol classes. The Framingham study, Arteriosclerosis, 3, 260-72 (1983)

11) Rifkind BM, Segal P : Lipid Research Clinics Program reference values for hyperlipidemia and hypolipidemia, JAMA, 250, 1869-72 (1983)

12) Yan $W, G u ~ D$, Yang $X$, et al : High-density lipoprotein cholesterol levels increase with age, body mass index, blood pressure and fasting blood glucose in a rural Uygur population in China, J. Hypertens., 23, 1985-9 (2005)

13) Wilson PW, Anderson KM, Kannel WB : Epidemiology of diabetes mellitus in the elderly. The Framingham study, Am. J. Med., 80, 3-9 (1986)
14) Davies CTM, DO Thomas, MJ White : Mechanical properties of young and elderly muscle, Acta. Med. Scand., 711, 219-226 (1988)

15) Forbes GB, Reina JC : Adult lean body mass declines with age : some longitudinal observations, Metabolism, 19, 65363 (1970)

16) Kohrt WM, Malley MT, Dalsky GP, et al : Body composition of healthy sedentary and trained, young and older men and women, Med. Sci. Sports. Exerc., 24, 832-7 (1992)

17) Lemieux S, Prud' homme D, Moorjani S, et al : Do elevated levels of abdominal visceral adipose tissue contribute to age-related differences in plasma lipoprotein concentrations in men?, Atherosclerosis, 118, 155-64 (1995)

18) Sial S, Coggan AR, Carroll R, et al : Fat and carbohydrate metabolism during exercise in elderly and young subjects, Am. J. Physiol., 271, E983-9 (1996)

19）香川芳子監修：家庭のおかずのカロリーガイドブック， 女子栄養大学出版部, 東京 (2002)

20）「栄養と料理」家庭料理研究グループ編：調理のための ベーシックデータ, 女子栄養大学出版部, 東京 (2003)

21）福原俊一，鈴鴨よしみ：SF-36v2 日本語版マニュアル, NPO 健康医療評価研究機構, 京都 (2004)

22）健康 - 栄養情報研究会: 国民健康 - 栄養の現状（平成17 年厚生労働省国民健康 · 栄養調査報告上り), 第一出版, 東 京（2008）

23) Carroll MD, Lacher DA, Sorlie PD, et al : Trends in serum lipids and lipoproteins of adults, 1960-2002, JAMA, 294, 1773-81 (2005)

24) Petersen KF, Befroy D, Dufour S, et al : Mitochondrial dysfunction in the elderly: possible role in insulin resistance, Science, 300, 1140-2 (2003)

25) Fraga MF, Ballestar E, Paz MF, et al : Epigenetic differences arise during the lifetime of monozygotic twins, Proc. Natl. Acad. Sci. U S A., 102, 10604-9 (2005)

26) Heller DA, de Faire U, Pedersen NL, et al : Genetic and environmental influences on serum lipid levels in twins, $\mathrm{N}$. Engl. J. Med., 328, 1150-6 (1993) 